\title{
Monitoring of woody plants in the park stands of the industrial cities in the south- east of Ukraine
}

\section{Elena Suslova*,}

\author{
Alexey Polyakov, \\ Lyudmila Kharkhota \\ Donetsk Botanical Garden \\ of the National Academy \\ of Sciences of Ukraine, \\ Donetsk, Ukraine
}

The paper presents data of the survey of industrial cities parklands of the south-east of Ukraine. We have identified the species composition (186 species and cultivars), age structure and state of woody plants in these parklands. In the course of our investigations we have revealed the most tolerant species with numerous high viability trees under the conditions of technogenic pollution.

Key words: species and cultivars, levels of height, vitality, intensity of growth

\section{INTRODUCTION}

At present, the south-east of Ukraine is an industrial region with a high potential for contamination of air, soil and groundwater. Apart from the industrial plants concentration in the area and their impact on the environment, this region is characterized by a continental climate with sharp fluctuations in temperature and low relative humidity, an expressed arid and dry winds phenomena, uneven distribution of rainfall during the year and a significant annual fluctuations in their quantity which greatly affects the overall state of urban environment. Despite high human impact in the industrial cities of the region

\footnotetext{
* Corresponding author. E-mail: esus@mail.ru
}

there is a system of green spaces as protective and recreational facilities. Parks constitute a major component of urban green space (Laptev, 2001), so monitoring of parklands is essential for objective assessment and prediction of the need to develop and conduct certain measures to improve them. At the Donetsk Botanical Garden of NAS of Ukraine (DBG) the research has been underway on woody species as for their gase absorption, dust absorption and ability to accumulate heavy metals in industrial areas (Tarabryn, 1973), environmental impact on the content of organic acids in leaves (Tarabrin et al., 1975), nitrogen compounds in the needles (Korshikov et al., 1995), the intensity of photosynthesis in trees and shrubs (Prysedsky, 1996), etc., selection of the most promising species and cultivars for a 
wide use in plantations of different categories (Polyakov, 2009). Comprehensive studies that show the dynamics of the plantations state were launched only in 2011-2012. Research data of these studies are important in decisionmaking to optimize tree stands in the urban environment basing on a scientifically sound approach to the formation of their composition and subsequent maintenance.

\section{MATERIALS AND METHODS}

The aim of our study was to determine the species composition and evaluate the life state of woody plants in the park stands of industrial cities of the region. A survey was conducted in 2011-2012 by means of a route-visual method. Taxonomic identity of plant species was determined by their specific morphological features. We determined some dendrometric parameters, such as the trunk diameter measured by means of callipers at the height of $1.3 \mathrm{~m}$ from the root collar; height of plants, measured by the BM altimeter and age of plants. Trees and shrubs were distributed into classes by the level of height by means of the methods conventionally used in dendrology (Pyatnytsky, 1960). Viability of plants was evaluated over 8-point scale by Savelieva (1975).

\section{RESULTS AND DISCUSSION}

Dendroflora of parklands includes 186 species and cultivars belonging to 75 genera, 33 families of the two sections. Some 37 species and cultivars are gymnosperms, 149 are angiosperms. Over 88 species and cultivars are represented by a biomorph of tree, 98 - by that of a bush. The most numerous are the Rosaceae Juss. family (37\% of the total number of plants), Cupressaceae Bartl. (11\%), Aceraceae Juss. (10\%). Families Ulmaceae Mirb., Berberidaceae Juss., Fabaceae Lindl. and Oleaceae Hoffmanns. et Link make 4 to $7 \%$, families Salicaceae Mirb., Hippocastanaceae DC., Pinaceae Lindl., Betulaceae S. F. Gray, Moraceae Link, Tiliaceae Juss., Cornaceae Dumort. and Hydrangeaceae Dumort. make 1 to $3 \%$, other families (Caprifoliaceae Juss., Bignoniaceae Juss., Fagaceae Dumort., Buxaceae Dumort. Etc.) make less than $1 \%$. The greatest number of plant species and cultivars belong to the family Rosaceae Juss. - 43 species and cultivar (23\% of the total), Cupressaceae - 26 (14\%), Berberidaceae - 13 (7\%), Salicaceae - 12 (6\%), Pinaceae - $11(6 \%)$. Almost half of the families is represented by only one species (Anacardiaceae Lindl., Buddleiaceae Wilholm, Buxaceae Dumort., Calycanthaceae Lindl., Hippocastanaceae DC., Juglandaceaea Rich. ex Kunth, Magnoliaceae Juss. etc.). Regarding the species composition, the richest families are as follows: Juniperus L. - 7 (8\%), Рориlus L. -6 (7\%), Acer L. and Spiraea L. - 5 (6\%), Ulmus L. -4 species (5\%). Cultivars of 30 species were found. The most numerous variety of cultivars was found in Thuja occidentalis $\mathrm{L}$. (8 cultivars), Berberis thunbergi DC. (6) and Swida alba (L.) Opiz (4).

Formation of urban green spaces should be focused on enriching of their species composition as mixed stands are more stable. Participation of each woody species in the stands must not exceed 5\%, as higher representation of any species can reduce the overall stability of the plantations. Based on the data analysis, the most common tree species are Robinia pseudoacacia L. (10\% of the total number of plants), Acer campestre L. (9.7\%), A. platanoides L. (7.5\%), Aesculus hippocastanum L. (7.2\%), Betula pendula Roth (5.3\%) (Fig. 1). Other tree species are much less common, their participation in the stands does not exceed 1-2\%. Some species and cultivars of woody plants that are restricted in their occurrence in green areas but are at the same time highly ornamental and rare enough are especially noteworthy. These rare specimens include Liriodendron tulipifera L., Acer platanoides 'Crimson King', Cerasus serullata (Lindl.) G. Don 'Kanzan', C. serullata 'Kikushidare', Betula pendula f. youngii (Th. Moore) C. K. Schneid.; the plants with weeping and spherical crown shape, such as Fraxinus excelsior L. 'Monophylla pendula', Ginkgo biloba L. f. pendula Carr., Acer platanoides f. globosum (Nichols.) Schwerin. 


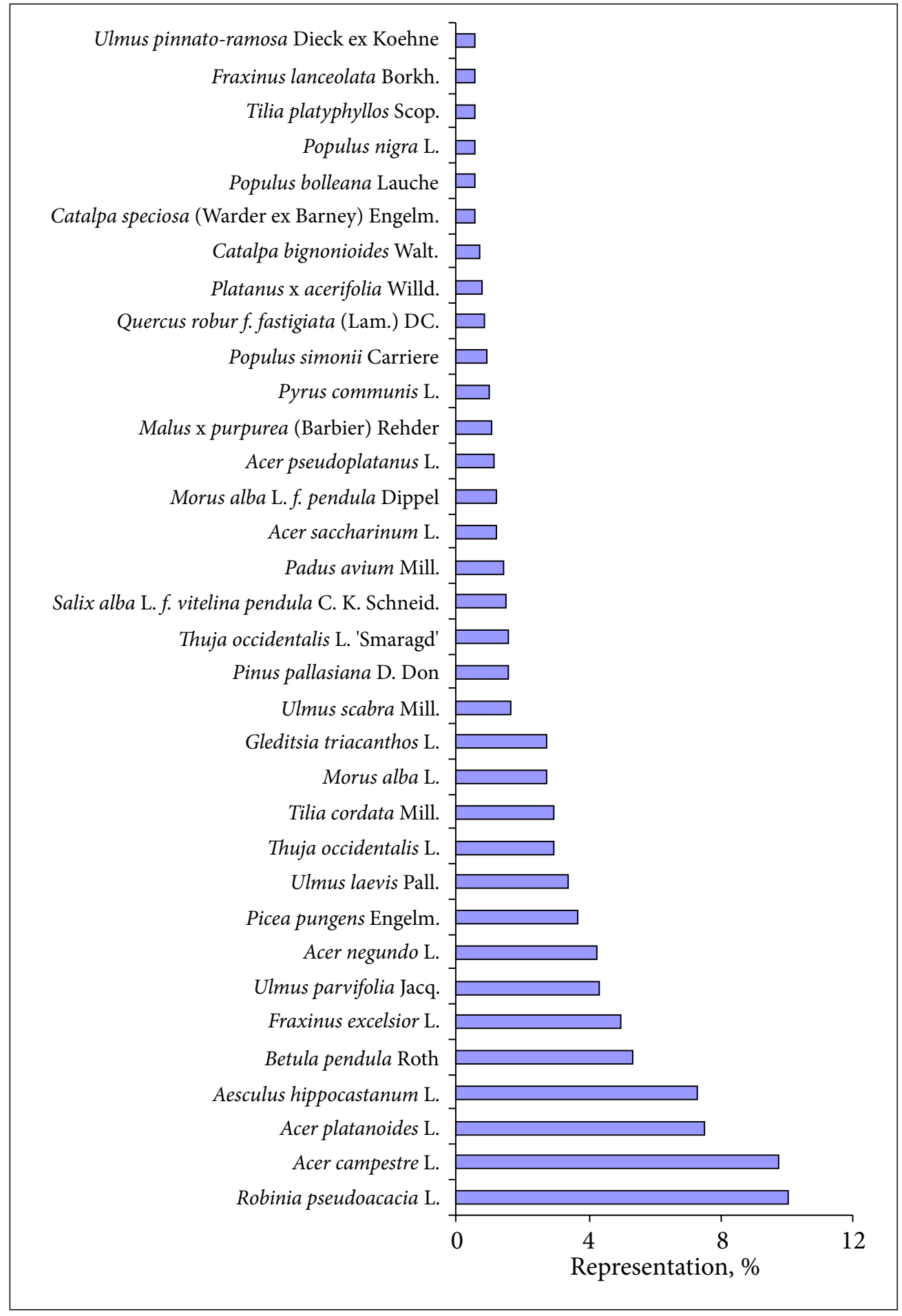

Fig. 1. Representation of woody plants in the park stands of industrial cities of the south-east of Ukraine

In most plantations shrubs are represented by hybrid tea rose varieties (17\%), species and cultivars of Physocarpus opulifolius (L.) Maxim. (11.5\%), Berberis thunbergii DC. and Spiraea japonica L. f. (7.1\%), Juniperus sabina L. (5\%),
Ligustrum vulgare L. (4.7\%). Many shrubs are represented by single plants.

Our distribution of trees and shrubs by height levels indicates that the parkland is dominated by trees of the fourth level - 
59 species and cultivars (67\% of the total number of trees). Juniperus virginiana L., Padus avium Mill., Pinus pallasiana D. Don, Morus alba L., Acer platanoides $f$. globosum, Picea pungens Engelm., Tilia cordata Mill., Robinia pseudoacacia $f$. globosa, etc. belong here. The second place is taken by trees of the third level of height - 21 species and cultivar (24\%). This class includes Larix sibirica Ledeb., Robinia pseudoacacia, Fraxinus lanceolata Borkh., Salix alba L. $f$. vitelina pendula C. K. Schneid., Betula pendula, Ulmus parvifolia Jacq., Pinus sylvestris L. and others. We have noted 9 species and cultivars (8\%), represented by the trees of the second level of height, namely Acer platanoides, A. pseudoplatanus L., A. saccharinum L., Aesculus hippocastanum, Populus bolleana Lauche, Fraxinus excelsior. Trees of the first level of height are absent from the structure of the investigated stands. Among the shrubs the dominant group is comprised of low species: cultivars of Juniperus squamata Buch.Ham. ex D. Don, J. $\times$ media Melle, Berberis thunbergii DC., Magonia aquifolium (Pursh) Nutt. (a total of 84 species and cultivars). Among high shrubs there are Juniperus communis L. 'Hibernica', Corylus avellana L., Syringa vulgaris L., Sambucus racemosa L. f. laciniata (W. Koch) Zabel (a total of 21 species and cultivar).

Plant age is an important indicator of the state and decorative features of plantations. In the course of the analysis of the park stands age structure we have revealed the trees aged 4 to 70 years (Table). The age group of 40 to 49 yearold trees $(33.7 \%$ of the total trees number) is the most numerous. Very significant in their number are the previous age groups: 10 to 19 years $-20.1 \%, 20$ to 29 years $-14.1 \%, 30$ to 39 years $-18.7 \%$. Number of the trees older than 60 years is $2.4 \%$ of the total, and the number of the trees older than 70 years makes only $0.1 \%$. In these age groups there are specimens of Robinia pseudoacacia, Salix alba f. vitelina pendula, Populus bolleana, Acer campestre, A. saccharinum, genus Ulmus L. species and single specimens of Gleditsia triacanthos L., Populus deltoides Bartr. ex Marshall, Quercus robur L. Environmental conditions, contemporary stressful environmental situation in general contribute to the weakening of the state and premature aging of woody plants, their susceptibility to diseases and pests, thus losing their decorative features and sustainability long before reaching the maximum age limits of their existence. As a result of these studies, we analyzed the viability of woody plants in the park stands. As shown in Fig. 2, the viability of a larger number of trees is evaluated in 6 to 8 points ( $79.6 \%$ of the total), they have no significant signs of aging. Approx. $1.4 \%$ of the trees are in critical condition (their viability is assessed in 1 to 3 points) and should be removed and some $1.1 \%$ are dry wood. The

Table. Distribution of trees by age and viability of the park stands of industrial cities of the south-east of Ukraine

\begin{tabular}{|c|c|c|c|c|c|c|c|c|c|c|}
\hline \multirow{2}{*}{$\begin{array}{l}\text { Viability, } \\
\text { points }\end{array}$} & \multicolumn{8}{|c|}{ Tree age, years } & \multirow{2}{*}{$\begin{array}{c}\text { Total } \\
\text { number, \% }\end{array}$} & \\
\hline & $<10$ & $10-19$ & $20-29$ & $30-39$ & $40-49$ & $50-59$ & $60-69$ & $>70$ & & \\
\hline 0 & & 0.20 & 0.29 & 0.31 & 0.22 & 0.04 & 0.02 & & 1.1 & $>=10$ \\
\hline 1 & & 0.09 & 0.04 & & 0.13 & & & & 0.3 & $7-10$ \\
\hline 2 & & & 0.02 & 0.15 & 0.07 & & 0.02 & & 0.3 & $4-7$ \\
\hline 3 & 0.04 & 0.09 & 0.09 & 0.15 & 0.22 & 0.11 & 0.04 & & 0.8 & $1-4$ \\
\hline 4 & & 0.04 & 0.69 & 0.49 & 0.99 & 0.38 & 0.20 & & 2.8 & $<1$ \\
\hline 5 & & 0.88 & 2.01 & 2.32 & 6.21 & 2.39 & 1.46 & & 15.3 & \\
\hline 6 & 0.04 & 1.57 & 1.46 & 5.02 & 5.22 & 2.08 & 0.20 & & 15.6 & \\
\hline 7 & 0.09 & 7.47 & 5.31 & 6.08 & 17.73 & 3.07 & 0.40 & 0.07 & 40.2 & \\
\hline 8 & 1.66 & 9.79 & 4.20 & 4.22 & 2.87 & 0.91 & 0.07 & 0.07 & 23.8 & \\
\hline $\begin{array}{c}\text { Total, } \\
\text { number, \% }\end{array}$ & 1.8 & 20.1 & 14.1 & 18.7 & 33.7 & 9.0 & 2.4 & 0.1 & 100 & \\
\hline
\end{tabular}




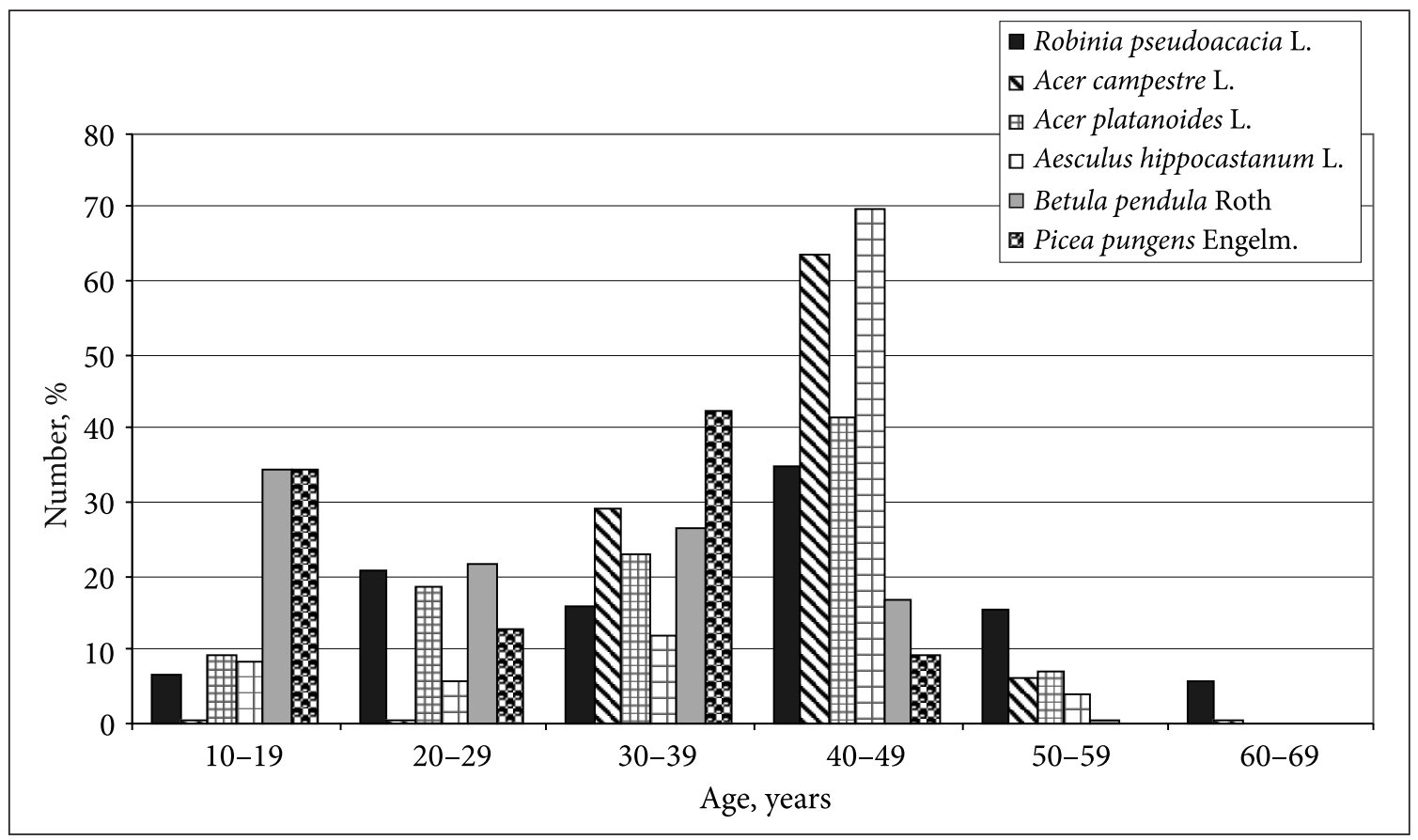

Fig. 2. Age groups of the main tree species in the park stands of the industrial cities of the south-east of Ukraine

highest viability is characteristic of the plants aged 10 to 40 years, a reduce in viability is observed ranging from 30-40 years (depending on the species). Thus, in the age group of 40 to 49 years there was a significantly reduced number of viable plants (by 3.5 to 7 times), evaluated in 6 to 8 points. In this group of plants, there is also a reduced number of trees in poor condition, evaluated in 0 to 3 points, compared to the previous age groups, due to the timely removal of old dry trees by utility service providers. In their species composition, the most diverse is the age group of 10 to 19 years. Among young trees there are $83 \%$ of the total number of tree species and cultivars of the plantation, indicating that there is a recruitment of highly decorative species, and mostly cultivars in the plantations in recent years. Age group of 40 to 49 year-old trees is represented by 43 species and cultivars, that of 20 to 29 year-old trees, 30 to 39 and 50 to 59 years-old trees include 30 to 36 taxa.

In addition to the age structure of parkland trees we analyzed the main tree species according to their age groups (Fig. 2). We found that Robinia pseudoacacia is represented by all age groups. Predominantly plants of this species aged 40 to 49 years (35\%), a sufficient number of young plants under 29 years (28\%) and also old trees aged over 60 years are present $(6 \%)$. Among young trees most numerous are Betula pendula and Picea pungens. The longevity of these highly ornamental trees under anthropogenic load does not exceed 40 years, thus young plants were planted in recent years. In the age group of 40 to 49 years the largest number of trees is represented, namely by Aesculus hippocastanum. Younger trees of this species are not present, because they were not planted in this region in recent years due to their marked susceptibility to Cameraria ohridella Deschka et Dimič, 1986, resulting in the loss of their ornamental features. Native species, such as Acer platanoides and A. campestre, characterized by considerable resistance to adverse conditions of the man-made environment, decorative features, longevity are quite numerous in different age groups. These species are worth of wider use, including park stands.

Analysis of the age structure of shrubs revealed that the highest number of plants is aged 6 to 10 years $(65.7 \%)$. The highest species 
diversity is also typical for plants of this age group, numbering more than 40 species and cultivars. This suggests the replenishment of parks in recent years with a large number of highly ornamental cultivars of shrubs and deciduous conifers, namely Berberis $\times$ ottawensis Schneid., B. thunbergii, Weigela $\times$ hybrida Jaeg., Spiraea japonica, Juniperus chinensis L., J. $\times$ media, Thuja occidentalis L., and different varieties of hybrid tea rose.

By their pace of growth, woody plants were divided into the following groups: fast-, average- and slow-growing. Fast-growing plants dominate the investigated stands making 58\% of the total number of parkland tree species. The average-growing species also make a significant percentage (34\%). The category of a slow-growing comprises makes only $8 \%$ of the tree species. As we have determined, most fast-growing trees (Robinia pseudoacacia, Acer platanoides, A. pseudoplatanus, A. saccharinum, Betula pendula, Fraxinus excelsior, Salix alba f. vitelina pendula, Gleditsia triacanthos, Morus alba L., Pinus pallasiana etc.) reached the age of 40 to 49 years (31.6\% of their total number) in park plantations. The fast-growing trees are almost equal in number (from $16.5 \%$ to $17.6 \%$ ) in the previous age groups, lower number of them $(12.2 \%)$ is the group aged 50 to 59 years, the bulk of fast-growing trees aged over 60 years is $3.7 \%$. Here belong the fast-growing tree species group where the oldest trees of the plantations aged more 70 years grow. The viability of the majority (30.7\%) fast-growing tree species is evaluated in 7 points, the viability of $16.7 \%$ and $23.7 \%$ of fast-growing trees is assessed in high points -6 and 8 , respectively. In the age group of 40 to 49 years there was an increasing percentage of trees whose viability was evaluated in $4-5$ points, i. e. plants that have marked signs of the deterioration of tree state, resulting in a mass die-back of apical shoots and some lateral and large skeletal branches, sprout growth on the tree trunks. This explains the reduction, by half or more, in the next age group of 50 to 59 years the total number of plants and those with viability, evaluated in 6 to 8 points. This fact indicates a further deterioration in their conditions, signs of aging that entail their removing from the stands. The curve describing the dependence of viability of the fast-growing plants from their age is shown in Fig. 3a. The high points of viability in young trees indicate a high percentage of seedling survival. When a tree reaches the age of 30 years a marked deterioration in the tree state takes place, apical shoots and some lateral branches die-back. Increased viability points in fast-growing trees aged more than 40 years are due to the timely removal of plants in a poor state from plantations.

Regarding average-growing trees (Acer campestre, Aesculus hippocastanum, Picea pungens, P. Abies (L.) Karst., Tilia cordata, T. platyphyllos
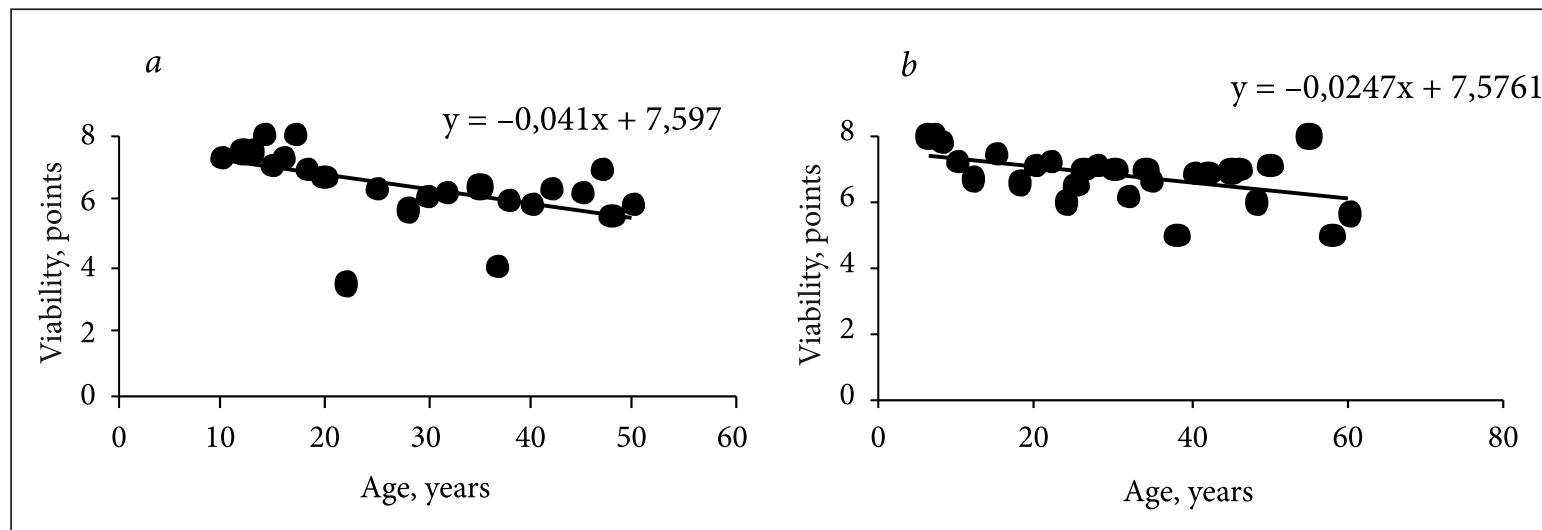

Fig. 3. Dependence of the viability of trees of the varying intensity growth of age in the park stands of the industrial cities of the southeast of Ukraine: $a$ - fast-growing trees, $b$ - average height of tree 
Scop., Thuja occidentalis, Quercus robur, etc.) we have noticed that trees aged 40 to 49 years (37.4\% of the total number of average-growing trees) dominated the stands. A large number of average-growing trees (26.1\%) are aged 10 to 19 years, a significantly lower number of them belongs to the age group of 50 to 59 years (3.5\%), average-growing trees older than 60 years are scarce. The viability of most tree species of average height was estimated by us in 7 points (57.2\%), a significant number of trees $(23.2 \%)$ was assessed in 8 points. As shown in Fig. 3b, in this group of trees a reduced viability is observed at the age of 35 to 40 years. Trees that lose their vital resources, are gradually cut down, their number is greatly reduced and then only healthy old trees are left in the stands.

Number of a slow-growing trees in plantations is insignificant. Most of them are aged 10 to $19(45.2 \%)$ due to the recent work on introduction of highly ornamental slow-growing trees in the parks. Older trees (20 to 40 years) are represented by a single species - Armeniaca vulgaris Lam., its viability is evaluated in 6 to 8 points.

\section{CONCLUSIONS}

As a result, we registered 186 species and cultivars of woody plants from 75 genera and 33 families in the park stands of industrial cities of the south-east of Ukraine. Fast-growing trees aged 40-49 years with viability estimated in $6-8$ points dominate the stands. Reduced viability, the appearance of aging signs in the industrial cities of the region is observed in the fast-growing trees when they reach the age of 30 years. In average-growing trees this process takes 40 years, in slow-growing trees -25 years. The results obtained show timeliness and relevance of launching the comprehensive monitoring, biomorphological and ecological studies to create optimal conditions and prognosis of longevity of trees in difficult conditions of the south-east of Ukraine. These data should be considered when planning measures on reconstruction of green areas and creation of new compositions using long-lived, tolerant and highly onamental species and forms according to current trends in green construction under the conditions of industrial areas.

Received 5 March 2013

Accepted 25 August 2013

\section{References}

1. Laptev OO. Introduktsiya ta aklimatyzatsiya roslyn $\mathrm{z}$ osnovamy ozeleneniya (Introduction and acclimatization of plants with the basics of gardening). Fitosotsiotsentr, Kyiv 2001; 128 p.

2. Tarabryn VP. Effect izbytochnogo soderzhaniya tyazhelykh metallov $\mathrm{v}$ vozdukhe i $\mathrm{v}$ pochve na rasteniya (Plant effect of excessive heavy metals content in the air and in the soil). Biofizicheskie aspekty zagryazneniya biosphery (Biophysical aspects of pollution of the biosphere). Moscow 1973; 145-7.

3. Tarabrin VP, Glukhova TI. Vplyv promyslovogo seredovyshcha na vmist organichnykh kislot u lystkakh derevnykh roslyn (Effect of industrial environment on the content of organic acids in leaves of woody plants). Introdutsiya ta eksperimentalna ekologiya roslyn (Introduction and experimental plant ecology) $1975 ; 4: 108-9$.

4. Korshikov II, Ignatenko AA. Izmenenie soderzhaniya azotistykh soedineniy $\mathrm{v}$ khvoe sosny obyknovennoy pod vliyaniem azotsoderzhaschikh emissiy khimkombinatov (Changes in content of nitrogen compounds in Scots pine needles under the effect of nitrogen-based emissions of chemical enterprises. Introduktsiya i akklymatyzatsiya roslyn (Introduction and acclimatization of plants) 1995; 22: 80-2.

5. Prysedsky JG. Vliyanie zagryazneniya vozdukha soedineyami ftora, sery i azota na intensivnost photosinteza drevesnykh i kustarnikovykh rasteniy (Effect of air pollution with compounds of fluorine, sulfur and nitrogen on photosynthesis intensity in woody and shrub plants). Introduktsiya and akklymatyzatsiya roslyn (Introduction and acclimatization of plants) 1996; 26: 54-8. 
6. Polyakov AK. Introduktsiya drevesnykh rasteniy $\mathrm{v}$ usloviyakh technogennoy sredy (Introduction of woody and shrub plants in conditions of technogenic environment). Noulidzh Publ., Donetsk 2009; 268 p.

7. Pyatnytsky SS. Kurs dendrolohyy (Course of dendrology). Kharkov University Ed., Kharkov 1960; 423 p.

8. Savelieva LS. Ustoychivost dereviev i kustarnikov $\mathrm{v}$ zaschitnykh lesonasazhdeniyakh (Tolerance of trees and shrubs in protective tree plantations). Lesnaya Promyshlennost, Moscow 1975; 168 p.
Elena Suslova, Alexey Polyakov, Lyudmila Kharkhota

\section{MEDINGUU AUGALỤ MONITORINGAS PRAMONĖS MIESTŲ PARKUOSE PIETRYČIŲ UKRAINOJE}

\section{Santrauka}

Straipsnyje pateikiami pramonès miestų parkų Pietryčių Ukrainoje tyrimų duomenys. Identifikuota rūšių sudètis (186 rūšys ir atmainos), amžiaus struktūra ir medingų augalų būklè parkuose. Tyrimo metu atskleistos rūšys, kurių medžių gyvybingumas technologinės taršos sąlygomis yra gana aukštas.

Raktažodžiai: rūšys ir atmainos, aukščio lygiai, gyvybingumas, augimo intensyvumas 